\title{
EFFECT OF PROPOLIS EXTRACT ON GUINEA PIG LUNG MAST CELL
}

\section{ORSI R. O. (1), SFORCIN J. M. (2), FUNARI S. R. C. (1), GOMES J. C. (3)}

(1) Department of Animal Production, School of Veterinary Medicine and Animal Husbrandy, FMVZ, UNESP, Botucatu, SP, 18618-000, Brazil; (2) Department of Microbiology and Immunology, Institute of Biosciences, UNESP, Botucatu, SP, 18618-000, Brazil; (3) Department of Pharmacology, Institute of Biosciences, UNESP, Botucatu, SP, 18618-000, Brazil.

ABSTRACT: The direct effect of ethanolic extract of propolis on guinea pig lung cell suspension containing mast cells, as well as its influence on the histamine release induced by antigen (ovoalbumin $10 \mu \mathrm{g} / \mathrm{ml}$ ) and ionophore A $23187(3 \mu \mathrm{M})$ were investigated. Propolis ethanolic extract $(300 \mu \mathrm{g} / \mathrm{ml})$ increased the histamine release in guinea pig lung suspension containing mast cells by a cytotoxic effect. Lower concentrations of propolis had no effect on histamine release. Our results demonstrated that propolis $(3,10,30$, and $100 \mu \mathrm{g} / \mathrm{ml})$ shows no significant effect on the histamine release induced by ionophore and antigen. Based on these results, we suggest that propolis could directly activate mast cells, promoting inflammatory mediators release by cytotoxic mechanisms, what could be related to allergic processes in propolis sensitive people.

KEY WORDS: mast cells, allergy, histamine, propolis.

\section{CORRESPONDENCE TO:}

J. M. SFORCIN, Departamento de Microbiologia e Imunologia, Instituto de Biociências, UNESP, Botucatu, SP, 18618-000, Brasil. Email: sforcin@ibb.unesp.br 


\section{INTRODUCTION}

Propolis has been widely used in folk medicine as an anti-inflammatory agent, attracting the researchers' interest to elucidate its biological properties. Propolis inhibits platelet aggregation, eicosanoid synthesis, rat paw edema, and adjuvantinduced arthritis, showing a potent anti-inflammatory action $(3,4,10)$.

The ethanolic extract of propolis showed an anti-inflamatory action on both chronic and acute inflammation (14). It also inhibited the histamine release induced by the compound 48/80 and concanavalin A, suggesting the presence of an unknown compound, non-flavonoid and with anti-inflammatory activity (11).

In some cases, after propolis use, few side effects, such as cutaneous eruption, lung dysfunction, allergy, and contact dermatitis, have been reported (1, 19, 20, 22). Isoprenyl caffeat present in propolis composition was indicated as a pro-hapten, which can be enzymatically oxidized in the skin cells and presented as an allergen for T cells (7).

Mast cells play a major role in the pathogenesis of allergy process by the elaboration of proinflammatory mediators. Mast cells secretion may be induced by immunological mechanisms or chemical agents, releasing some mediators such as histamine, heparin, serine proteases, prostaglandin, leukotrienes, platelet activating factor, and cytokines. These mediators are responsible for the allergic reactions, well known as "immediate hypersensivity reactions" $(5,15,18)$.

The aim of this work was to investigate the direct effect of propolis ethanolic extract on the guinea pig lung cell suspension containing mast cells, as well as its influence on the histamine release induced by antigen (ovoalbumin $10 \mu \mathrm{g} / \mathrm{ml}$ ) and ionophore $A$ $23187(3 \mu \mathrm{M})$, in order to provide evidences about the possible mechanisms involved in the hypersensivity observed in some people after propolis use.

\section{MATERIAL AND METHODS}

\section{Propolis hydroalcoholic solution}

Propolis was collected by Africanized honeybees and obtained from the apiary located in Lageado Farm (FMVZ - UNESP). A 30\% propolis ethanolic solution was prepared; after a week, this solution was filtered, the final concentration was calculated, and its dry weight $(120 \mathrm{mg} / \mathrm{ml})$ was obtained. Specific dilutions of this solution were prepared in appropriate media for each assay (13). 


\section{Animals and sensitizations}

Thirty Dunkin-Hartley guinea pigs $(250 \mathrm{~g})$ received a single dose of ovalbumin (100 $\mathrm{mg} / \mathrm{kg}$, intraperitonially) dissolved in saline. Animals were used after 21 days of the sensitization.

\section{Cell suspension}

The cellular suspensions containing mast cells were obtained by enzymatic dispersion with collagenase IA (6). Briefly, small pieces (approximately $1 \mathrm{~mm}^{3}$ ) of lung tissue were incubated (90 min, with continuous agitation at $37^{\circ} \mathrm{C}$ ) in Tyrode's solution containing bovine serum albumin ( $1 \mathrm{mg} / \mathrm{ml})$, collagenase (160 units $/ \mathrm{ml})$, and Hepes $(10 \mathrm{mM})$. A mixture of oxygen $(95 \%)$ and $\mathrm{CO}_{2}(5 \%)$ was bubbled in the incubation medium every $30 \mathrm{~min}$. After the enzymatic dispersion, the remaining tissue was mechanically disrupted by expression through a syringe and filtered through gauze moistened with Tyrode's solution. Cells were recovered by centrifugation ( $150 \mathrm{~g}, 5 \mathrm{~min}$ at $4^{\circ} \mathrm{C}$ ), washed twice, first in Hepes-Tyrode containing bovine serum albumin $(0.5 \mathrm{mg} / \mathrm{ml})$ and after only in Tyrode's solution. Cells were ressuspended in Tyrode's solution.

\section{Histamine release and fluorometric assay}

After $5 \mathrm{~min}$ at $37^{\circ} \mathrm{C}$, cells $(0.5 \mathrm{ml})$ received $20 \mu \mathrm{l}$ of different concentrations of propolis $(3,10,30,100$, and $300 \mu \mathrm{g} / \mathrm{ml})$ and were incubated during $10 \mathrm{~min}$ at $37^{\circ} \mathrm{C}$. After this period, the histamine release inducers were added. The secretion process was interrupted by adding cold Tyrode $\left(4^{\circ} \mathrm{C}-1.0 \mathrm{ml}\right)$. After centrifugation (5 min, 150 $g$ at $4^{\circ} \mathrm{C}$ ), the supernatants were taken and equal volumes of Tyrode were added to the cell pellets. All the samples received perchloric acid at a final concentration of 0.4 $\mathrm{N}$.

Histamine extraction and fluorometric assay were performed by continuous flow using an automatic apparatus (17). The histamine release was expressed as a percentage of the total content (supernatant plus pellets) discounting the spontaneous release.

\section{Statistical Analysis}

Data were analyzed using the analysis of variance (ANOVA), followed by multiple comparison tests by the Tukey-Kramer method. The significance level was set at $p<0.05(23)$. 


\section{RESULTS AND DISCUSSION}

Some cases of allergy due to propolis components have been reported, but the possible mechanisms and the compounds responsible for such allergic reaction still deserve further investigation.

Propolis ethanolic extract $(300 \mu \mathrm{g} / \mathrm{ml})$ increased the histamine release in guinea pig lung suspension containing mast cells. However, it can be seen that this effect is not related to selective stimuli but due to cytotoxic effects, since the histamine release induced by propolis was not inhibited by sodium cyanide (data not shown). Moreover, this effect was observed only with a high concentration of propolis $(300 \mu \mathrm{g} / \mathrm{ml})$. Propolis had no effect on histamine release in lower concentrations.

Reports have pointed out that ethanol can induce urticaria without showing evidence of cytotoxic histamine release after oral ingestion in high concentration, and low concentrations can cause urticaria by specific histamine release $(12,21)$. Previous works in our laboratory showed that ethanol (in concentrations equal to those used to prepare the ethanolic extract of propolis) does not have any effect on the spontaneous histamine release (16), suggesting that the effect observed was due to the propolis components.

Although propolis shows anti-inflammatory properties, there are few reports of its side effects, such as allergic contact dermatitis (1). Propolis is characterized by a complex chemical composition, with both stimulant and inhibitory compounds, as well as synergistic ones. More than 180 compounds (such as flavonoids, phenolic acid and their derivatives, among others) were identified in propolis composition (2).

Some cases of contact allergy due to propolis are not related to one main allergen, but to several ones, depending on the source plant of collection by bees (9). Propolis constituents are strong contact sensitizers when administered in guinea pig skin, being the 1,1-dimethylallyl caffeic acid ester the main agent responsible for the allergic process (8).

In this work, we observed that propolis induced mast cell histamine release, suggesting that this stimulant action may occur due to its constituents concentration in the hydroalcoholic solutions, depending either on the predominance of one compound or on the synergism of several propolis constituents. Further investigations with isolated constituents of propolis would permit to elucidate their biological properties. 
Histamine release induced by antigen and ionophore A 23187 was analyzed using propolis concentrations lower than $300 \mu \mathrm{g} / \mathrm{ml}$, which had no direct effect on spontaneous histamine release. Our results demonstrated that propolis $(3,10,30$, and $100 \mu \mathrm{g} / \mathrm{ml}$ ) does not show a significant effect on the histamine release induced by ionophore. This result indicated that propolis does not interfere with the ionic flow promoted by the ionophore in the cell. Other authors observed that both ethanolic and water extracts of propolis inhibited the histamine release induced by compound $48 / 80$, suggesting that these extracts possess an anti-allergic action (11).

With regards to the histamine release induced by antigen, propolis had also no significant effect, suggesting that this product does not interfere with the immunologic process of mast cells degranulation.

In view of these results, we suggest that only high concentrations of propolis may directly activate mast cells, promoting the inflammatory mediators release by cytotoxic mechanisms. These results may be related to the allergic process in propolis sensitive people. We encourage propolis use to non-allergic people because of its several biological and therapeutical properties.

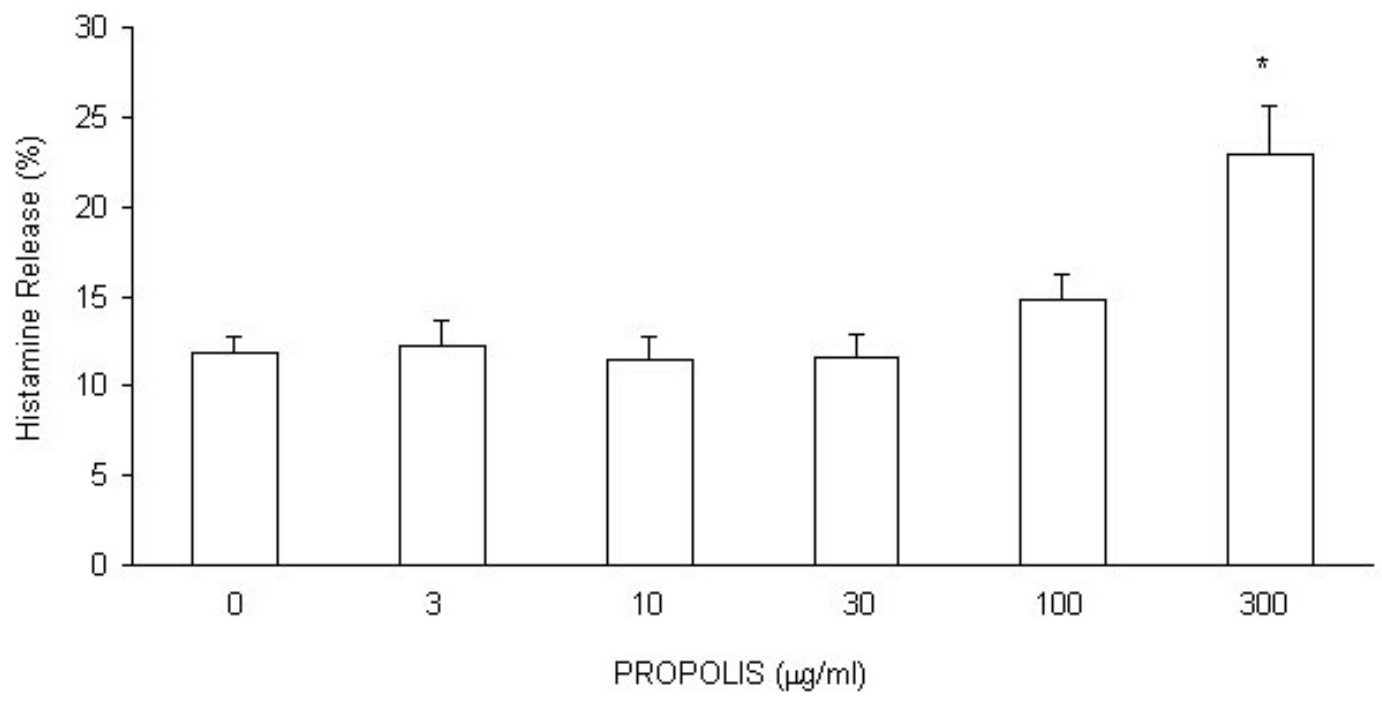

Figure 1. Effect of hydroalcoholic extract of propolis on the guinea pig lung cell suspension containing mast cells. Results are means \pm standard error of mean (SEM) of 7 similar assays.

* Statistically different from histamine release in the absence of propolis $(p<0.05)$. $F=16,828$ 


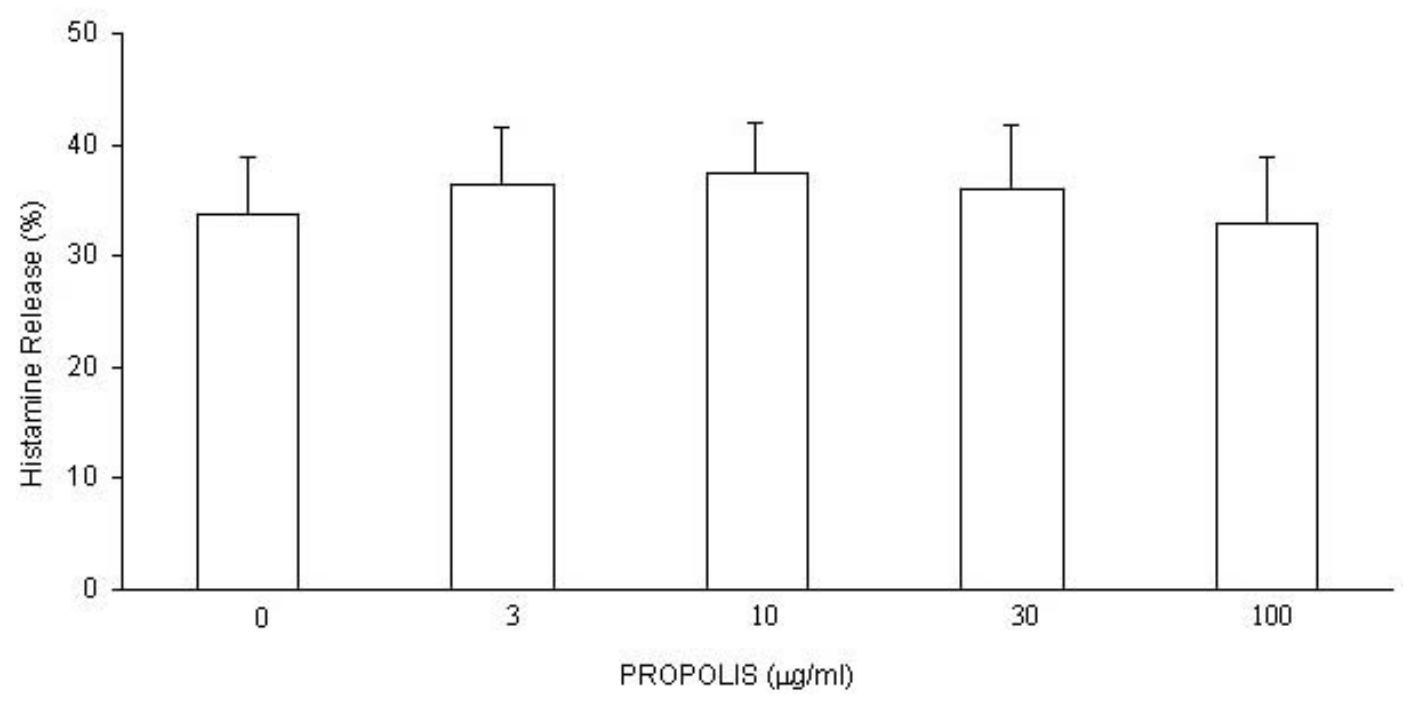

Figure 2. Effect of hydroalcoholic extract of propolis on the histamine release induced by ionophore A 23187 on the guinea pig lung cell suspensions containing mast cells. Results are means \pm standard error of mean (SEM) of 7 similar assays.

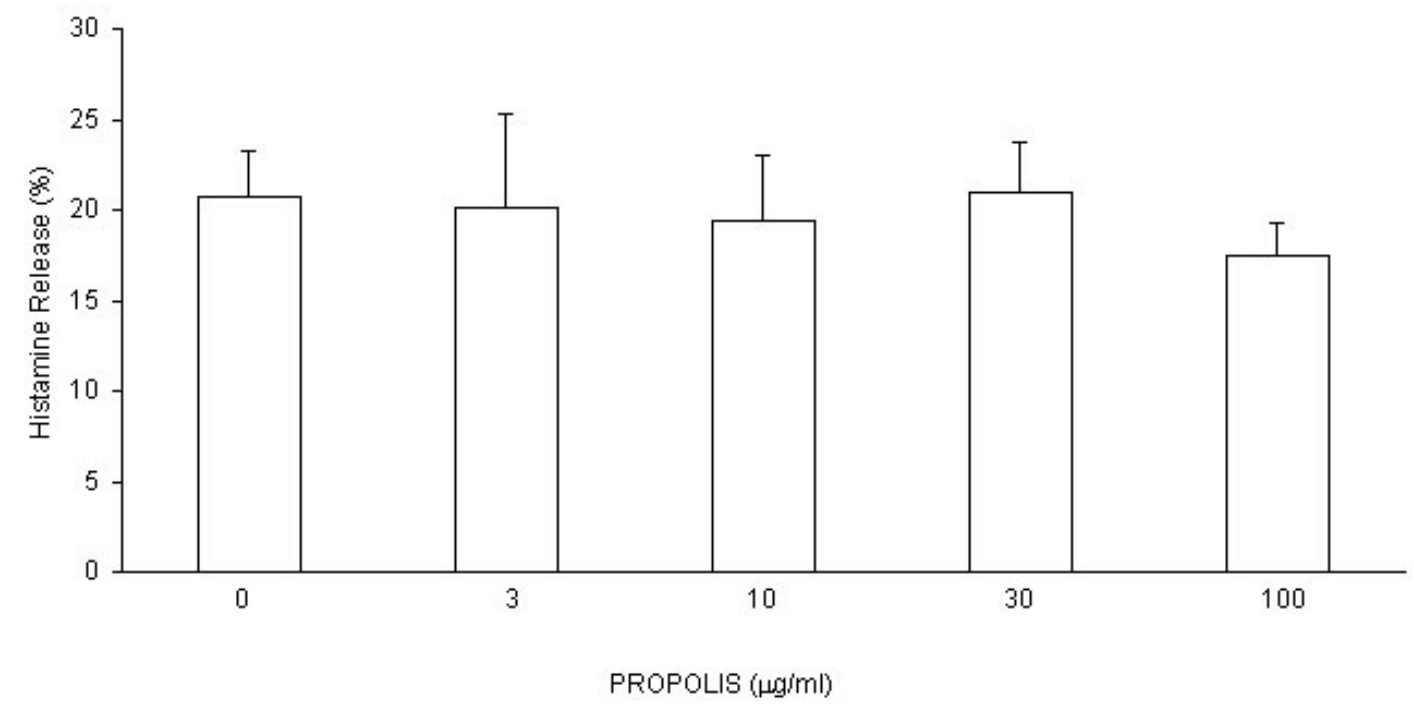

Figure 3. Effect of hydroalcoholic extract of propolis on the histamine release induced by antigen on the guinea pig lung cell suspensions containing mast cells. Results are means \pm standard error of mean (SEM) of 7 similar assays. 


\section{REFERENCES}

1 ANGELINI G., VENA GA., MENEGHINI CL. Psoriasis and contact allergy to propolis. Contact Dermatitis, 1987, 17, 251-3

2 BANKOVA V., DYULGEROV A., POPOV S., EVSTATIEVA L., KULEVA L., PUREB O., ZAMJANSAN Z. Propolis produced in Bulgaria and Mongolia: phenolic compounds and plant origin. Apidologie, 1992, 23, 79-85

3 BANSKOTA AH., TEZUKA Y., KADOTA S. Recent progress in pharmacological research of propolis. Phytother. Res., 2001, 15, 561-71

4 BURDOCK GA. Review of the biological properties and toxicity of bee propolis (propolis). Food Chem. Toxicol., 1998, 36, 347-63

5 CHURCH MK., HOLGATE ST., SHUTE JK., WALLS AF., SAMPSON AP. Mast cell - derived mediators. In: MIDDLETON E., ELLIS EF., YUNGINGER JW., REED CE., ADKINSON NF., BUSSE WW. Allergy: principles and practice. 5.ed. Saint Louis: Mosby, 1998: 146-67

6 GOMES JC., DI STASI LC., SGARBOSA F., BARATA LES. Pharmacological evaluation of the inhibitory effect of extracts from Anchieta salutaris on the histamine release induced in the rat and the guinea pig. Int. Arch. Allergy Immunol., 1994, 103, 188-93

7 HANSSON C., EZZELARAB M., STERNER O. Oxidative activation of the propolis hapten isoprenyl caffeate. Acta Derm. Venereol., 1995, 75, 34-6

8 HAUSEN BM., WOLLENWEBER E., SENFF H., POST B. Propolis allergy. I. Origin, properties, usage and literature review. Contact Dermatitis, 1987, 17, $163-70$

9 HEGYI E., SUCHY V., NAGY M. Propolis contact allergy. Hautarzt, 1990, 41, 6759

10 KHAYAL MT., EL-GHAZALY MA., EL-KHATIB AS. Drugs Exp. Clin. Res., 1993, 19, 197

11 MIYATAKA H., NISHIKI M., MATSUMOTO H., FUJIMOTO T., MATSUKA M., ISOBE A., SATOH T. Evaluation of propolis (II): effects of brazilian and chinese propolis on histamine release from rat peritoneal mast cells induced by compound 48/80 and concanavalin A. Biol. Pharm. Bull., 1998, 21, 723-9

12 ORMEROD AD., HOLT PJA. Acute urticaria due to alcohol. Br. J. Dermatol., $1983,103,723-4$ 
13 ORSI RO., FUNARI SRC., SOARES AMVC., CALVI SA., OLIVEIRA SL., SFORCIN JM., BANKOVA V. Immunomodulatory action of propolis on macrophage activation. J. Venom. Anim. Toxins, 2000, 6, 205-19

14 PARK EH., KAHNG JH. Supressive effects of propolis in rat adjuvant arthritis. Arch. Pharm. Res., 1999, 22, 554-88

15 PEARCE FL. Calcium and histamine secretion from mast cells. Prog. Med. Chem., 1982, 19, 59-109

16 RUIZ CM., GOMES JC. Effects of ethanol, acetaldehyde and acetic acid on histamine secretion in guinea pig lung mast cell. Alcohol, 2000, 20, 133-8

17 SHORE PA., BURKHALTER A., COHN VH. A method for the fluorometric assay of histamine in tissue. J. Pharmacol. Exp. Ther., 1959, 127, 182-6

18 SIRAGANIAN RP. Biochemical events in basophil or mast cells activations and mediator release. In: MIDDLETON E., ELLIS EF., YUNGINGER JW., REED CE., ADKINSON NF., BUSSE WW. Allergy: principles and practice. 5.ed. Saint Louis: Mosby, 1998: 204-27

19 TERAKI Y., SHIOHARA T. Propolis-induced granulomatous contact dermatitis accompanied by marked lymphadenopathy. Br. J. Dermatol., 2001, 144, 12778.

20 THOMAS P., HANS-CHRISTIAN K., BERNHARD P. Propolis-induced allergic contact dermatitis mimicking pemphigus vulgaris. Arch. Dermatol., 1998, 134, 511-3

21 TING S., RAULS DO., ASHBAUGH P., MANSFIELD LE. Ethanol-induced urticaria - a case report. Ann. Allergy, 1988, 60, 527-30

22 YOUNG E. Sensitivity to propolis. Contact Dermatitis, 1987, 16, 49-50

23 ZAR JH. Biostatiscal analysis. 2.ed. Englewood: Cliffis:Prentice-Hall, 1984. 718. 